\title{
河口模型を用いた流出土砂の周辺海域への 粒径別移動に及ぼす波の影響検討
}

池野正明 ${ }^{1} \cdot$ 清水隆夫 $^{2}$

\begin{abstract}
河口から流出した土砂の周辺海域への運ばれ方に及ぼす波の影響を粒径別に調べるための平面実験を実施した．粗砂・レ キ 2 種混合砂, 細砂・粗砂・レキ 3 種混合砂掞よび均一粒径砂を対象に, 右斜め入射の規則波を作用させた場合と作用させ ない場合を比較した，波が作用する場合，発達した速い沿岸流が水深中層に見られ，河川流は大きく左に曲げられ，河川流 が蛇行して河口前面に海浜循環流が形成された．細砂は浮遊砂となってこの沿岸流に乗り河口左側の広い範囲に運ばれると ともに，循環流により河口前面を移動した．粗砂やレキは掃流状態で水底近くを移動するため，沿岸流によってさらわれず， 循環流によって河口前面の限られた範囲を移動した.
\end{abstract}

\section{1.はじめに}

河口から周辺海域へ流出する土砂の粒度分布は広く， 細砂からレキまで様々である。このように，河口から流 出した様々な粒径の土砂は，波や海浜流に対して漂砂挙 動が異なると考えられる。しかしながら，河口流出した 粒径の異なる土砂の周辺海域への運ばれ方にどのような 違いがあるかについては，未解明な点が多い。そこで， 本研究は, 現象を単純化し, 河床変動により河口から流 出した土砂の周辺海域への運ばれ方に及ぼす波作用の影 響を粒径別に調べるための実験を実施した。

\section{2. 河口模型を用いた実験}

\section{（1）実験模型および実験条件}

図-1 に示すように，平面水槽 (長さ $35 \mathrm{~m}$ ，幅 $45 \mathrm{~m}$, 媣さ $1.1 \mathrm{~m})$ の $1 / 50$ 勾配固定床上に, 模型縮尺 $1 / 50$ 相 当の河口模型 (長さ $10.8 \mathrm{~m}$, 幅 $0.5 \mathrm{~m}$, 高さ $0.5 \mathrm{~m}$ ) を設 置し, その上流にポンプ, 流量測定堰, 整流水槽を接続 し河川流量を制御した。河口模型内に砂試料を初期厚さ $20 \mathrm{~cm}$ で敷き詰め，河口先端が汀線となるように水深を 設定した。砂試料は，図-2に示した細砂，粗砂，レキ （中央粒径 $0.08 \mathrm{~mm}, 0.5 \mathrm{~mm}, 5 \mathrm{~mm}$ ) を用い, 表-1に 示すように, 均一粒径砂, 粗砂・レキ 2 種混合砂（重量 比 $1: 1$ ), 細砂・粗砂・レキ 3 種混合砂 (重量比 4 : $3: 3)$ の場合の河口流出実験を行った. まず, 波が作 用しない条件で，6ケース (CASE1〜6)の実験を行った. 河川流量は $3,7 \mathrm{l} / \mathrm{s}$ の 2 種類変化させた. 上流から土砂 供給は行わず，放流時間は河床厚さが初期の半分に低下 するまでの時間とした。つぎに，波による影響を検討す るため, 上記のうち 4 ケース (CASE7〜10)の実験条件に 対して，造波波高 $4 \mathrm{~cm}$, 周期 $1 \mathrm{~s}$, 入射角右 20 度の規

1 正会員 工博 (財)電力中央研究所 環境科学研究所 2 正会員 工修 (財)電力中央研究所 環境科学研究所

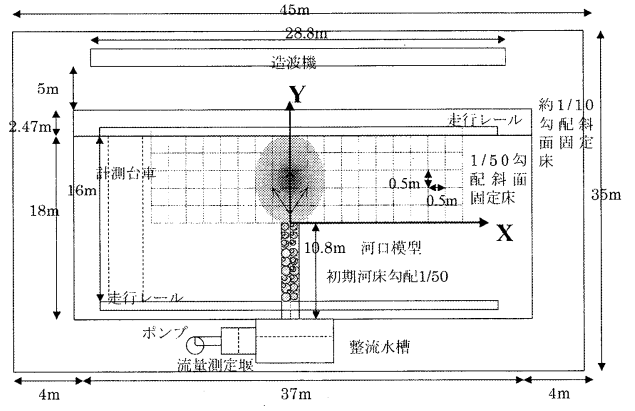

図-1 平面水槽と河口模型と座標系

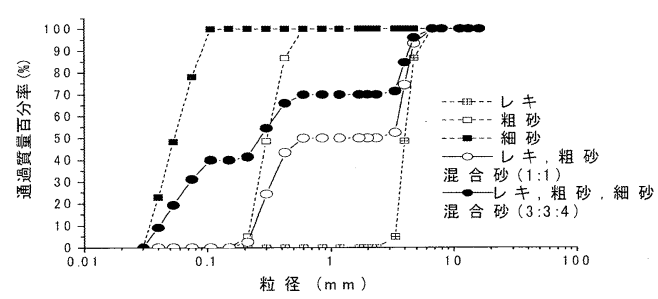

図-2 使用した砂試料の粒度分布

表-1 実験ケースの諸元

\begin{tabular}{c|c|c|c|c|c}
\hline $\begin{array}{c}\text { 実験 } \\
\text { CASE }\end{array}$ & 砂の条件 & 初期混合率 & $\begin{array}{c}\text { 河川流量 } \\
(\mathrm{l} / \mathrm{s})\end{array}$ & $\begin{array}{c}\text { 放流時間 } \\
(\mathrm{min})\end{array}$ & 波作用 \\
\hline 1,2 & 均一砂 & 細砂 $100 \%$ & 3.0 & 6.0 & 無, 無 \\
\hline 3,7 & 均一砂 & 粗砂 $100 \%$ & 3.0 & 10.0 & 無, 有 \\
\hline 4,8 & 均一砂 & 粗砂 $100 \%$ & 7.0 & 6.0 & 無, 有 \\
\hline 6,10 & 2 種混合砂 & $\begin{array}{c}\text { 粗砂 } 50 \% \\
\text { レキ } 50 \%\end{array}$ & 7.0 & 8.0 & 無, 有 \\
\hline 3 種混合砂 & $\begin{array}{c}\text { 細砂 } 40 \% \\
\text { 粗砂 } 30 \% \\
\text { レキ } 30 \%\end{array}$ & 3.0 & 8.0 & 無, 有 \\
\hline
\end{tabular}

則波を作用させた。波は放流開始と同時に作用させ，波 作用時間を放流時間と同じにした.CASE1,2では，波 作用無の場合の実験の再現性を調べた。

河口の模型縮尺に対して砂の粒径が相対的に大きいた め相似性が問題となるが，細砂は浮遊移動が卓越しレキ 
は掃流移動のみ，粗砂はその中間で掃流移動が卓越する 実験条件を設定した。

また, 表-1のケースとは別に, 河口模型内に砂を敷 き詰めず河口から土砂流出がなく河川流のみが所定の流 量で海域に流出する場合, およびそれに斜め入射波が作 用する場合の実験を行い河川流と河口周辺海域の中層流 速と波高の平面分布を電磁流速計と容量式波高計で測定 した.

\section{（2）土砂の測定・解析方法}

河床と河口周辺堆積形状を小型連続式砂面計で測定し た. 混合砂の実験では，0.5 1 m ピッチに河床表層の サンプリング（長さ $10 \mathrm{~cm}$, 幅 $50 \mathrm{~cm}$, 河床表面下 1 $\mathrm{cm}$ ）を実験前後に行い, 乾燥させた後, 粒度分析によ り河床表層の砂の混合率（粒径別重量比）と平均粒径を 求めた。河口周辺海域の固定床上に, 図-1に示すよう に, $0.5 \mathrm{~m} \times 0.5 \mathrm{~m}$ ピッチの格子を記入し, 実験後ゆっ くり排水し, 各格子内に堆積した河口流出土砂を土砂量 に応じてトレイあるいは紙コップで採取し乾燥させた後, 粒度分析した。これにより, 河口部周辺に堆積した土砂 の混合率と平均粒径掞よび粒径別堆積量の平面分布を求 めた．粒径別の流出土砂総量に対する各地点粒径別堆積 量の割合について, 同じ河床材料, 放流条件で波が作用 する場合としない場合の差分をとり, 波の影響分を求め た.

\section{3. 波高分布と流速分布の特性}

図-3(a)に，河川流量 $3 l / \mathrm{s}$ の場合の河口周辺海域にお ける波高の平面分布特性を示す。図-3(b) (c)に, 河川 流量 $3 l / s$ で, 波が作用しない場合および波が作用する 場合の流れ（時間平均流）の平面分布特性を示す.

図-3(a)によると，沖の波高 $4 \mathrm{~cm}$ で造波された波は, $1 / 50$ 勾配斜面上での浅水変形により, 河口から沖へ 4 $\mathrm{m}$ 離れた地点 $(\mathrm{Y}=4 \mathrm{~m})$ では波高 $6 \mathrm{~cm}$ に増幅されてい る.この地点付近が砕波点にあたり, この地点から岸向 きに河口に近づくにしたがい砕波により波高が減衰して いる.

図-3(b)によると，波無の場合，河口から $40 \mathrm{~cm} / \mathrm{s}$ 程 度の流速で河川中心軸沖方向に流出している. さらに, 河川中心軸沖方向に河口加 $4 \mathrm{~m}$ 程度離れると $(\mathrm{Y}=4$ $\mathrm{m})$, 流速 $10 \mathrm{~cm} / \mathrm{s}$ 以下に減少している. 河川中心軸上 以外では流速は非常に小さい.

これに対し, 図-3(c)の波作用有の場合, 河口から沖 へ $4 \mathrm{~m}$ 離れた地点 $(\mathrm{Y}=4 \mathrm{~m})$ が砕点であり, $0 \mathrm{~m}<\mathrm{Y}<$ $4 \mathrm{~m}$ の領域が砕波帯となるため, 斜め入射波の砕波によ り沿岸方向左向き $(\mathrm{X}$ 軸負方向)に発達した速い沿岸流 が水深中層に見られる．これによって，河川流は大きく 左に曲げられると同時に沿岸流も蛇行し, 流速 $30 \mathrm{~cm} / \mathrm{s}$

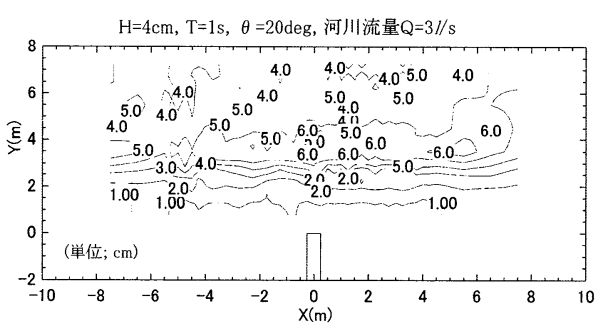

(a) 波高の平面分布特性

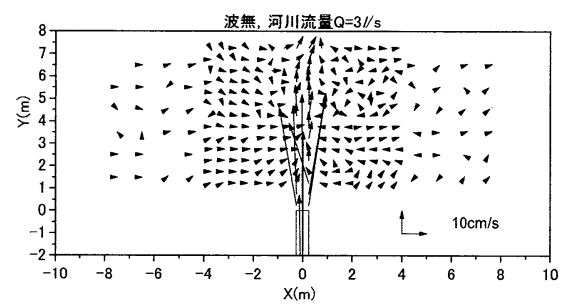

（b） 中層における流れの平面分布特性（波作用無）

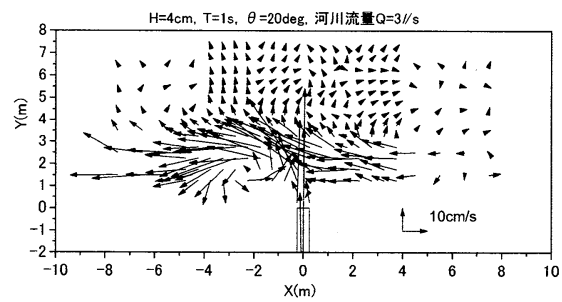

（c）中層における流れの平面分布特性（波作用有）

図-3 波高，流れの平面分布特性（河川流量 $3 l / \mathrm{s}$ )

程度の強い海浜循環流が座標 $(-3 \mathrm{~m}, 2 \mathrm{~m})$ 付近を循環 流中心に発生している.

岡安ら (1992) は， $1 / 20$ 勾配斜面上を斜め入射する規 則波の砝波带内の海浜流の 3 次元分布を詳細に測定し, 斜め入射波による砕波帯内の岸沖方向の流速は水面付近 では岸向きであるが中層以深で沖向きの戻り流れとなる こと, 沿岸方向の流速はほほ対数分布となり水面付近か ら水深中層で最大となることが報告されている．本実験 では, 電磁流速計により水深中層の流速しか測定できな かったが, 沿岸流の本体は捉えられていると推察される.

図の掲載は省略するが, 流量 $7 l / \mathrm{s}$ の場合では, 河口 から最大流速 $80 \mathrm{~cm} / \mathrm{s}$ 程度の河川流が流出し, 沿岸流 による河川流の曲げられ方が図-3(c)より弱くなり, 循 環流の中心が座標 $(-3 \mathrm{~m}, 3 \mathrm{~m})$ 付近へと沖へ $1 \mathrm{~m}$ 移動 した.

\section{4. 地形変化と粒径別移動特性}

（1）河床の地形変化, 表層平均粒径, 混合率

紙面の都合上，混合砂の実験結果を中心に述べる. 


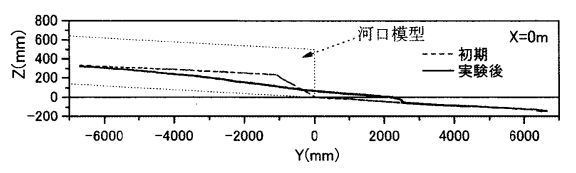

(a) 河床の地形変化

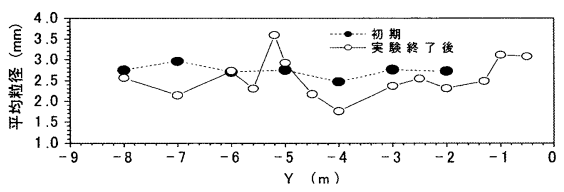

(b) 河床表層の平均粒径

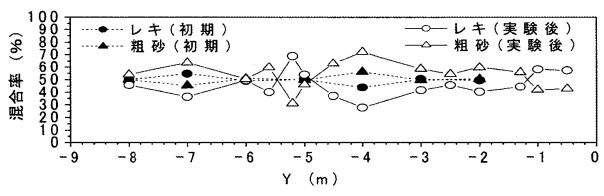

(c) 河床表層の混合率

図-4 河床の地形変化と表層の平均粒径と混合率 (粗砂・レキ 2 種混合砂, 流量 $7 \mathrm{l} / \mathrm{s}$ )

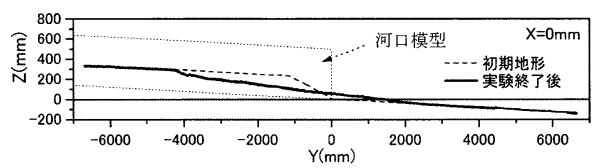

(a) 河床の地形変化

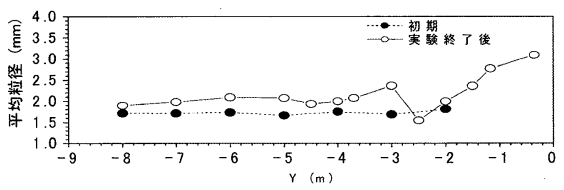

(b) 河床表層の平均粒径

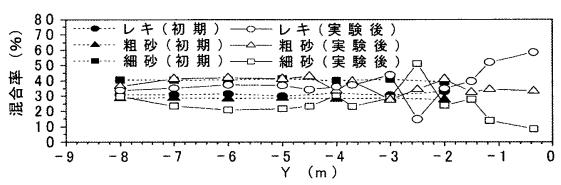

(c) 河床表層の混合率

図-5＼cjkstart河床の地形変化と表層の平均粒径と混合率 (細砂・粗砂・レキ 3 種混合砂, 流量 $3 l / \mathrm{s}$ )

図-4 (a) (b) (c)に, CASE9（粗砂・レキ 2 種混合砂, 流 量 $7 \mathrm{l} / \mathrm{s}$, 波有）の河床の地形変化と表層の平均粒径およ び混合率を示す. 河口先端付近 $(\mathrm{Y}=1 \mathrm{~m})$ から $6 \mathrm{~m}$ 上流 $(\mathrm{Y}=-6 \mathrm{~m})$ までの区間で，河床低下後にほほ $1 / 35$ の河 床勾配となる連続的な河床が形成されている. $6 \mathrm{~m}$ 上流 $(\mathrm{Y}=-6 \mathrm{~m})$ から $7 \mathrm{~m}$ 上流 $(\mathrm{Y}=-7 \mathrm{~m})$ までの区間では, 河床の低下量は小さい. 流量 $7 l / \mathrm{s}$ を 8 分間放流した後 の河床表層の平均粒径は, 縦断方向に大きく変動し, 河
口から $5 \mathrm{~m}$ 上流地点 $(\mathrm{Y}=-5 \mathrm{~m})$ で $3.5 \mathrm{~mm}$ と初期平均 粒径 $2.8 \mathrm{~mm}$ よりも大きく粗粒化した箇所が見受けられ る. $\mathrm{Y}=-8 \sim-5.5 \mathrm{~m}$ の区間では $2.3 \sim 2.5 \mathrm{~mm}$, $\mathrm{Y}=-4.5 \sim-1.5 \mathrm{~m}$ の区間では $1.8 \sim 2.5 \mathrm{~mm}$ と初期の 平均粒径 $2.8 \mathrm{~mm}$ よりも小さくなり細粒化している.レ キの混合率は, $\mathrm{Y}=-5 \mathrm{~m}$ の地点で, $68 \%$ となり, 平均 粒径の増大に対応している. $\mathrm{Y}=-8 \sim-5.5 \mathrm{~m}$ の区間 ではレキの混合率が 35〜 48\%, $\mathrm{Y}=-4.5 \sim-1.5 \mathrm{~m}$ の 区間ではレキの混合率が 25〜 $42 \%$ と初期の混合率 $50 \%$ よりも小さくなり細粒化している。これは，レキによる 遮蔽効果により, 粗砂は一様な粗砂の場合よりも移動し にくくなり，逆にレキは一様なレキの場合よりも移動し やすくなったためと推察される (平野, 1971 ; 芦田・道 上, 1972).

図-5(a) (b) (c)に, CASE10（細砂・粗砂・レキ 3 種混 合砂, 流量 $3 l / \mathrm{s}$, 波有）の河床の地形変化と表層の平均粒 径および混合率を示す. $\mathrm{Y}=1 \mathrm{~m}$ から $\mathrm{Y}=-4.5 \mathrm{~m}$ まで の区間で，河床低下後に平均的にはほぼ $1 / 27$ の勾配と なる河床が形成されているが，連続一様勾配とならず， 小さな河床変動の凹凸が見受けられる. $\mathrm{Y}=-4.5 \mathrm{~m}$ か ら $\mathrm{Y}=-7 \mathrm{~m}$ までの区間では, 河床の低下量は小さい. 流量 $3 \mathrm{l} / \mathrm{s}$ を 8 分間放流した後の河床表層の平均粒径は 全体的に初期平均粒径 $1.7 \mathrm{~mm}$ よりも大きく粗粒化して いる. 特に, 河口部付近 $(\mathrm{Y}=-1.5 \sim 0 \mathrm{~m})$ の平均粒径が 大きく粗粒化が著しい. 細砂の混合率は, 縦断方向に変 動しながら全体的に低下している. 細砂は主に浮遊砂と なって河口から海域へ多量に流出していた.レキと粗砂 は掃流砂移動であるが相対的に取り残され粗粒化した。

（2）河口流出土砂の堆積地形, 平均粒径, 混合率

図-6 (a) (b) (c)に, CASE6 と CASE10（細砂・粗砂 · レキ 3 種混合砂, 流量 $3 \mathrm{l} / \mathrm{s}$, 波無有）の河口流出土砂の 堆積地形とその平均粒径および混合率の平面分布の比較 を示す。

本放流条件で河口から流出した混合砂のうち, 細砂は 主に浮遊砂として, 粗砂は主に掃流砂として, レキも掃 流状態で運ばれる（芦田・道上，1972; Itakura and Kishi, 1980).このため, 細砂は河口周辺海域の広範囲 に運ばれ堆積する（砂層厚が薄く砂面計で検出できない 地点はサンプリングで確認済み).これに対し, 粗砂や レキは流れが速い河口前面域に堆積場所が限られる. 波 作用無の堆積地形コンターと比較すると, 波作用有のコ ンターが右沖にシフトしている.これは，後述するよう に, 沿岸流が蛇行して発生した海浜循環流により右沖に 運ばれたものと推察される.

波作用無の平均粒径と混合率をみると, 堆積土砂の中 心部 $(-0.5 \mathrm{~m}<\mathrm{X}<0.5 \mathrm{~m}, 0 \mathrm{~m}<\mathrm{Y}<1 \mathrm{~m})$ の粒径 が $2 \mathrm{~mm}$ 以上と, 初期平均粒径 $1.7 \mathrm{~mm}$ よりも大きい. こ 

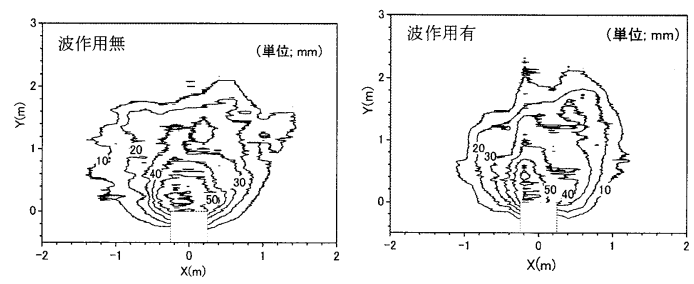

（a）河口流出土砂の堆積地形の比較
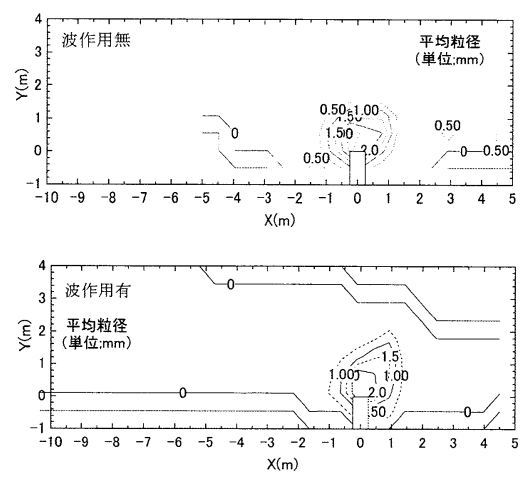

(b) 海域堆積土砂の平均粒径の比較
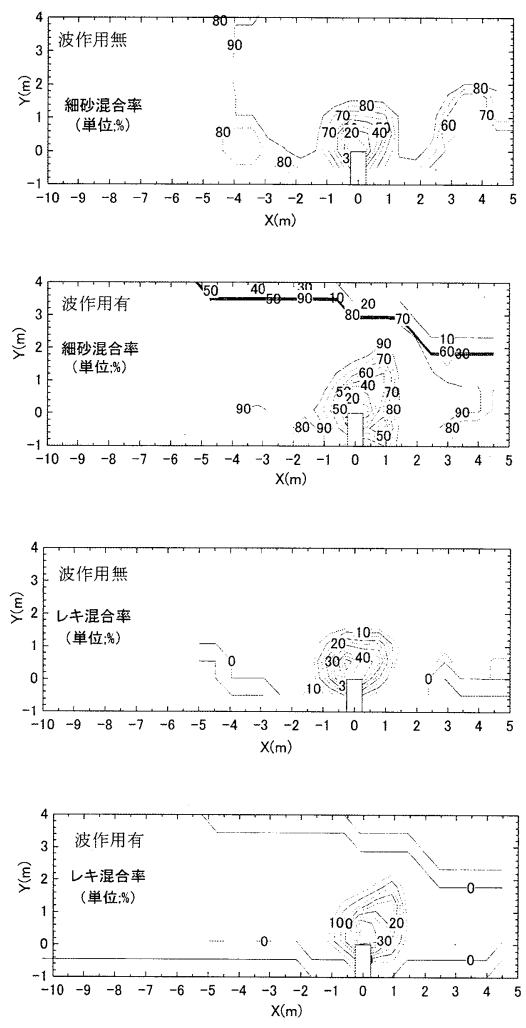

（c）海域堆積土砂の混合率の比較

図-6 河门流出土砂の堆皘地形, 平均粒待, 混合率の比較 (細砂・粗砂・レキ 3 種混合砂, 流量 $3 \mathrm{l} / \mathrm{s}$ )
の場所では, レキの混合率が 35〜 50\%, 粗砂の混合率 が 40〜 60\%となる.この場所では, 細砂の混合率が 30〜 10\%に低下している. 堆積土砂中心部から外側に いくに従って, 平均粒径がしだいに小さくなり, 細砂の 混合率が 60〜 $100 \%$ にしたいに増加し，粗砂とレキの混 合率が 20〜0\%としだいに低下する。レキや粗砂は主に 掃流砂として海域に流出しその後, 流れの強さが弱くな るにしたがい，まず河口近くでレキが堆積しその外側に 粗砂が堆積していくためである.つぎに，波作用の有無 を比較すると, 波作用有では, 左向き（X座標負方向） の沿岸流と大きく曲げられた河川流が蛇行して形成した 海浜循環流により, 浮遊状態の細砂は河口の海域下手側 に $10 \mathrm{~m}$ 離れた地点 $(\mathrm{X}=-10 \mathrm{~m})$ まで運ばれて堆積して いる．これに対し，波作用無では，河口から沿岸方向に $5 \mathrm{~m}$ 離れた地点 $(\mathrm{X}=-5 \mathrm{~m})$ まで運ばれて堆積している ことから, 波の作用により, 細砂は約 2 倍堆積範囲が沿 岸方向に広がっている. 細砂の河口から沖方向への堆積 範囲は，波作用無が $\mathrm{Y}=8 \mathrm{~m}$ の地点まで及んだが，波作 用有では，せいぜい $\mathrm{Y}=4 \mathrm{~m}$ の地点までのとどまってお り，波により浮遊細砂が岸向きに押し戻されていた。

\section{5. 河口流出土砂の波による影響}

\section{(1) 粗砂・レキ 2 種混合砂 (CASE5 と CASE9)}

図-7(a)（b)に，粗砂とレキの堆積場所の波作用によ る影響分を示す。図-7によれば，河口前面の限られた 範囲に流出した粗砂とレキは，波の作用により, $\mathrm{Y}=0 \sim 1 \mathrm{~m}$ の区間および $\mathrm{Y}=2 \sim 3 \mathrm{~m}$ の区間から $\mathrm{Y}=1 \sim 2 \mathrm{~m}$ の区間に移動したことを意味している.こ れは，沿岸流により曲げられた河川流が蛇行して形成し た海浜循環流の作用により，土砂が $\mathrm{Y}=1 \sim 2 \mathrm{~m}$ の区間 に集められたものと推察される．波は粒径の異なる粗砂 とレキを同じ方向に移動させたと推察される.

(2) 細砂・粗砂・レキ 3 種混合砂 (CASE6 と CASE10)

図-8 (a) (b) (c)に, 細砂, 粗砂, レキの堆積場所の波 作用による影響分を示す. 図-8によれば，河口周辺の 広い範囲に流出した細砂のうち，まず，河口から比較的 近い前面領域の細砂は, 沿岸流により曲げられた河川流 が蛇行して水深が浅い範囲に形成した海浜循環流の作用 により， $\mathrm{X}=-4 \sim-2 \mathrm{~m}, \mathrm{Y}=0 \sim 2.2 \mathrm{~m}$ の区間および $\mathrm{X}=1 \sim 2.5 \mathrm{~m}, \mathrm{Y}=1.2 \sim 3.4 \mathrm{~m}$ の区間から $\mathrm{X}=-2 \sim 1$ $\mathrm{m}, \mathrm{Y}=0 \sim 2.4 \mathrm{~m}$ の区間に集められたと推察される.つ ぎに, 河口から離れた海域の細砂は, 斜め入射波の砕波 帯で，水深中層に発達した左向き（X座標負の方向） の強い沿岸流によって浮遊砂になって移動する沿岸漂砂 として河口右側から河口左側（沿岸流卜手側）の広い範 囲に移動したと考えられる。

つぎに，河口前面の限られた範囲に流出した粗砂とレ 


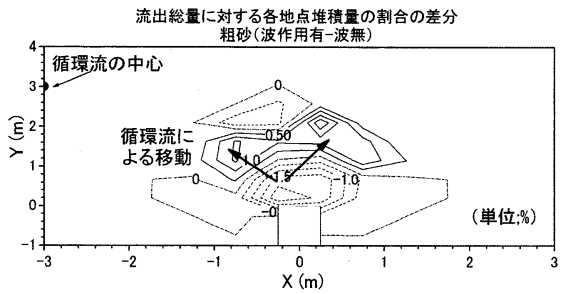

(a) 粗砂堆積場所の波による影響分

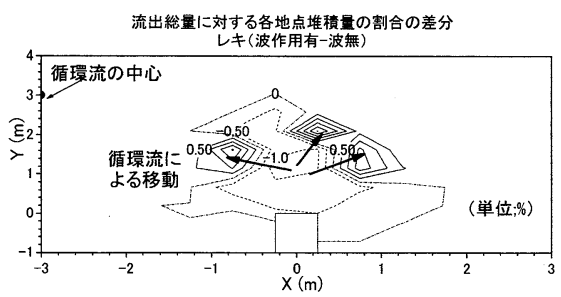

(b) レキ堆積場所の波による影響分

図-7 河口流出土砂堆積場所の波による影響分(CASE5,9)

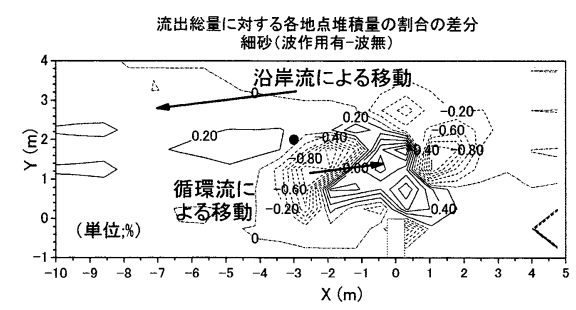

（a）細砂堆積場所の波による影響分

流出総量に対する各地点堆積量の割合の差分

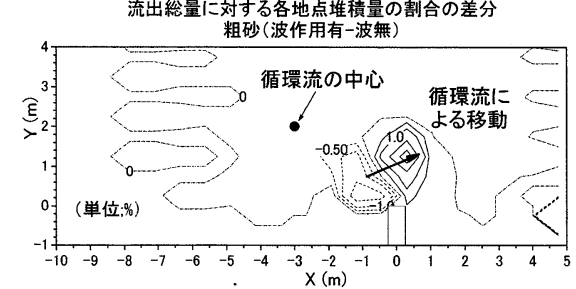

(b) 粗砂堆積場所の波による影響分

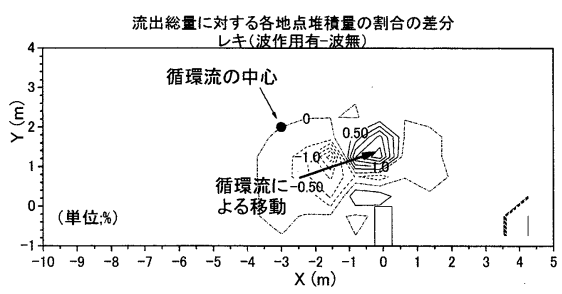

(c) レキ堆積場所の波による影響分

図-8 河口流出土砂堆積場所の波による影響分 (CASE6,10)

キは，掃流砂として水底近くを移動するため，上記沿岸 流によってさらわれず，沿岸流により曲げられた河川流
が蛇行して水深が浅い範囲に形成した海浜循環流のみに より, $\mathrm{X}=-3 \sim-1 \mathrm{~m}, \mathrm{Y}=0 \sim 1.5 \mathrm{~m}$ の区間から $\mathrm{X}=$ -1〜1 $\mathrm{m}, \mathrm{Y}=1 \sim 2 \mathrm{~m}$ の区間に集められたと考えられ， 波は粗砂とレキを同じ方向に移動させていると推察され る.

\section{6. 結 論}

(1)粗砂・レキ 2 種混合砂の場合, 粗砂は一様な粗砂の場 合よりも移動しにくく，逆にレキは一様なレキの場合 よりも移動しやすくなった結果, 河床は細粒化した.

(2)細砂・粗砂・レキ 3 種混合砂の場合, 浮遊砂として細 砂が多く流出するため，河床は粗粒化した。

(3)右斜め入射波が作用した場合, 河口下手側に発達した 速い沿岸流が水深中層に見られ, 河川流は大きく左に 曲げられ，河口から流出した細砂は浮遊砂となってこ の沿岸流に乗り，河口左側の広範囲の領域に運ばれた。 粗砂やレキは掃流砂として水底近くを移動するため, 沿岸流によってさらわれず，河口前面の限られた領域 に堆積した。

(4)細砂は沿岸流により河川流が蛇行して河口前面の水深 が浅い範囲に形成した海浜循環流による移動分と沿岸 流による河口左側の広い範囲への移動分の両方が生じ, 粗砂とレキは河口前面の上記循環流による移動分のみ 生じた。

本実験を実施するにあたり，(株)セレスの協力を得た ことを付記して謝意を表する。

\section{参 考 文 献}

芦田和男 - 道上正規 (1972)：移動床流れの抵抗と掃流砂量に関す る基礎的研究, 土木学会論文報告集, 第 206 号, pp. 59-69.

岡安章夫・原孝司・柴山知也 (1992) : 斜め入射波による砕波帯 内定常流の 3 次元分布, 海岸工学論文集, 第 39 巻, pp. 66-70. 熊田貴之 (2004)：沿岸および岸沖漂砂による粒径分級を考慮した 海浜変形モデルに関する研究, 日本大学学位論文, $163 \mathrm{p}$.

黒木幹男 • 尹 種秀 (2003) : 河口前面テラスの変形過程及び粒度 組成変化, 水工学論文集, 第 47 巻, pp. 709-714.

椹木 亨·出口一郎・片上貴文 (1987) : 河口流出砂の堆積形状に 及ほす河口処理工の影響, 第 34 回海岸工学講演会論文集, pp. $377-381$.

千 受京・出口一郎・石川裕夏 (1998)：河口砂州の崩壊と崩壊土 砂の海域での堆積に関する研究, 海岸工学論文集, 第 45 巻, pp. 606-610.

平野宗夫 (1971) : Armoring を伴う河床低下について, 土木学会 論文報告集，第 195 号, pp. 55-65.

山本幸次・張 達平・佐藤慎司・田中茂信 (1998)：海岸における 底質の分級に関する研究, 土木研究所資料, 第 3592 号, 建設 省土木研究所河川部海岸研究室, $78 \mathrm{p}$.

Itakura, T. and Kishi, T. (1980) : Open channel flow with suspended sediments, J. of Hyd. Div., ASCE, Vol.106, HY8, pp. $1325-1343$ 